\title{
PENGARUH PERSEPSI KUALITAS PELAYANAN DAN KEPUASAN PELANGGAN TERHADAP MINAT PEMBELIAN ULANG PADA BRASTAGI SUPERMARKET RANTAUPRAPAT
}

\author{
Sori Salbiah Lubis ${ }^{1}$, Bayu Eko Broto ${ }^{2}$ \\ ${ }^{1}$ Alumni Sarjana Ekonomi STIE Labuhanbatu \\ ${ }^{2}$ Dosen STIE Labuhanbatu
}

\begin{abstract}
ABSTRAK
Penelitian ini bertujuan untuk untuk mengetahui pengaruh persepsi kualitas pelayanan dan kepuasan pelanggan terhadap minat pembelian ulang pada Brastagi Supermarket Rantauprapat. Sampel penelitian ini berjumlah 96 orang yang diambil menggunakan rumus Supramono dan Haryanto. Teknik penentuan sampel adalah metode Purposive Sampling. Metode analisis yang dipergunakan adalah metode analisis deskriptif, metode analisis statistik yang terdiri dari uji asumsi klasik, analisis regresi linier berganda, pengujian signifikan simultan dan pengujian signifikan parsial serta pengujian koefisien determinasi.

Berdasarkan hasil uji hipotesis secara parsial (uji t) diketahui bahwa persepsi kualitas pelayanan $\left(\mathrm{X}_{1}\right)$ berpengaruh positif dan signifikan terhadap minat pembelian ulang pada Brastagi Supermarket Rantauprapat, dimana nilai $t_{\text {hitung }}>t_{\text {tabel }}$ yaitu 5,376 $>$ 1,66140 dengan signifikansi $0,000<0,05$. Kepuasan pelanggan (X2) juga berpengaruh positif dan signifikan terhadap minat pembelian ulang pada Brastagi Supermarket Rantauprapat, dimana nilai $t_{\text {hitung }}>t_{\text {tabel }}$ yaitu $7,602>1,66140$ dengan signifikansi $0,000<0,05$. Berdasarkan hasil uji hipotesis secara simultan (uji F) diketahui bawah pesepsi kualitas pelayanan $\left(\mathrm{X}_{1}\right)$ dan kepuasan pelanggan $\left(\mathrm{X}_{2}\right)$ secara bersama-sama berpengaruh positif dan signifikan terhadap minat pembelian ulang pada Brastagi Supermarket Rantauprapat, dimana nilai $F_{\text {hitung }}>F_{\text {tabel }}(82,733>3,09)$ dengan taraf signifikansi $0,000<0,05$. Melalui pengujian koefisien determinasi diperoleh nilai Adjusted $R$ square sebesar 0,632, yang berarti $63,2 \%$ minat pembelian ulang dapat dijelaskan oleh persepsi kualitas pelayanan dan kepuasan pelanggan, sedangkan sisanya 36,8\% dapat dijelaskan oleh faktor lain yang tidak diteliti oleh penelitian ini.
\end{abstract}

Kata kunci : Persepsi kualitas pelayanan, Kepuasan pelanggan, Minat pembelian ulang.

\section{Pendahuluan}

Brastagi Supermarket merupakan salah satu perusahaan eceran (retail) yang bergerak dalam bidang penjualan produkproduk seperti : peralatan elektronik, perlengkapan rumah tangga, perlengkapan sekolah dan kantor, kebutuhan bayi dan anak, makanan dan minuman, pakaian, pembersih, perawatan kecantikan, dan sebagainya. Ketertarikan penulis memilih Brastagi Supermarket karena retail tersebut merupakan salah satu perusahaan eceran yang sangat memperhatikan kualitas produk dan pelayanan yang ditawarkan. Brastagi Supermarket juga sering melakukan penawaran produk yang dipaketkan dengan harga yang lebih ekonomis, contohnya mie instant yang dipaketkan dalam lima bungkus dijual dengan harga 
yang lebih ekonomis dibandingkan dengan membeli per bungkusnya. Brastagi Supermarket membeli lebih memiliki motto, yaitu "Brastagi Bicara Quality" yang artinya Brastagi Supermarket lebih menonjolkan kualitasnya baik dari produk, pelayanan, dan harga. Secara teoritis, setiap kali seseorang membeli suatu barang atau jasa, ia berharap barang atau jasa tersebut akan mampu memberikan kegunaan maksimum. Hal ini sejalan dengan pendapat Tjiptono (2008:179) bahwa setiap konsumen adalah rational economic man yang memiliki alasan rasional dan membuat pilihan rasional dalam setiap pembelian produk dan jasa. Konsumen menjadi lebih jeli dalam memilih perusahaan yang tetap dan sesuai untuk mendapatkan produk atau jasa yang diinginkannya. Dalam hal ini persepsi kualitas pelayanan merupakan salah satu faktor yang mempengaruhi minat konsumen untuk melakukan pembelian ulang terhadap suatu perusahaan. Pembelian ulang adalah suatu reaksi yang riil atas keberhasilan program pemasaran suatu produk. Perusahaan harus dapat menciptakan strategi pemasaran yang baik untuk dapat menciptakan keberhasilan tersebut. Salah satunya adalah menciptakan kualitas pelayanan yang baik atas produk yang ditawarkan.

$$
\text { Menurut Aaker }
$$

persepsi kualitas (perceived quality) dapat didefenisikan sebagai persepsi pelanggan terhadap keseluruhan kualitas atau keunggulan suatu produk atau jasa layanan berkaitan dengan apa yang diharapkan oleh pelanggan. Persepsi kualitas tidak dapat ditetapkan secara objektif karena merupakan suatu persepsi dan melibatkan apa yang penting bagi pelangganya. Persepsi kualitas yang tinggi terhadap sesuatu merek akan membentuk suatu citra yang positif bagi merek tersebut yang menjadi salah satu faktor untuk melakukan pembelian. Brastagi Supermarket selalu menawarkan produk yang berkualitas. Hal ini dapat dilihat dari produk yang ditawarkan seperti makanan dan minuman, buahbuahan serta sayur-sayuran selalu di sediakan dalam keadaan yang segar (fresh), berkualitas dan terbaik. Brastagi Supermarket juga selalu mengutamakan pelayanan dan kepuasan serta kenyamanan konsumen dalam berbelanja. Brastagi Supermarket selalu melatih karyawannya untuk selalu besikap ramah dan tanggap terhadap pelangannya dengan menyediakan kotak saran apabila terdapat keluhan dan bagian informasi yang dibentuk untuk membantu pelangganya dalam memperoleh informasi yang dibutuhkan.

Faktor lain yang juga mempengaruhi pembelian ulang adalah kepuasan pelanggan. Kepuasan pelanggan merupakan tingkat perasaan dimana seseorang menyatakan hasil perbandingan atas kinerja produk atau jasa yang diterima dan yang diharapkan. Banyak cara yang digunakan perusahaan untuk memuaskan kebutuhan konsumen. Perusahaan yang telah mampu memuaskan konsumen dan memiliki konsumen yang setia cenderung mampu bertahan dalam perubahan kondisi ekonomi. Konsumen akan memberikan respon tertentu sebagai hasil evaluasi terhadap kesenjangan antara harapan dengan kinerja produk. Kepuasan tersebut akan tercapai jika harapan konsumen mengenai nilai suatu produk sesuai dengan nilai yang diterima. Jika konsumen merasa puas, maka kemungkinan besar konsumen tersebut akan melakukan pembelian ulang. Namun pada kondisi sebaliknya, jika konsumen 
merasa tidak puas maka kemungkinan akan berpindah membeli produk yang lain dan tidak menggunakan produk tersebut lagi.

Persepsi kualitas pelayanan merupakan persepsi pelanggan terhadap pelayanan pembelian secara keseluruhan. Persepsi pelanggan terhadap kualitas pelayanan Brastagi Supermarket akan dapat memberikan dampak positif bagi pelanggan yang kemudian akan menciptakan minat bagi pelanggan untuk mengambil keputusan melakukan pembelian di Brastagi Supermarket tersebut.

\section{Tinjauan Pustaka}

\section{Uraian Teoritis}

Menurut Aaker (2008:124)

persepsi kualitas (perceived quality) dapat didefenisikan sebagai persepsi pelanggan terhadap keseluruhan kualitas atau keunggulan suatu produk atau jasa layanan berkaitan dengan apa yang diharapkan oleh pelanggan. Persepsi kualitas (Perceived quality) merupakan persepsi yang menyeluruh terhadap suatu merek yang didasarkan pada dimensidimensi yang termasuk di dalam karakteristik produk tersebut. Persepsi kualitas tidak bisa ditetapkan secara objektif karena merupakan suatu persepsi dan melibatkan apa yang penting bagi pelanggannya.

Keberhasilan suatu pemasaran produk dapat ditentukan melalui kualitas pelayanan, dimana kualitas pelayanan yang diterima konsumen dinyatakan dalam besarnya perbedaan antara harapan atau keinginan konsumen dengan persepsi mereka. Kualitas pelayanan merupakan tingkat keunggulan yang diharapkan pelanggan. Apabila pelayanan yang diterima atau dirasakan sesuai dengan yang diharapkan, maka kualitas pelayanan dikatakan baik dan memuaskan. Sebaliknya, apabila pelayanan yang diterima atau dirasakan tidak sesuai (di bawah) dengan yang diharapkan, maka kualitas pelayanan dikatakan buruk atau tidak memuaskan. Dimensi dari kualitas pelayanan terdiri dari penampilan fisik, keandalan, ketanggapan, jaminan dan empati yang berpengaruh terhadap niat pembelian ulang (Laksana 2008).

Kotler (2009:36) berpendapat kepuasan pelanggan adalah perasaan suka/tidak kepada seseorang terhadap suatu produk setelah membandingkan antara persepsi terhadap hasil produk dengan harapan. Apabila pelanggan merasa puas, maka pelanggan akan membeli kembali produk dan pelanggan cenderung akan memberikan referensi yang baik terhadap produk kepada orang lain. Kepuasan pelanggan dapat mempengaruhi perubahan sikap (dalam pilihan supplier) yang pada gilirannya berpengaruh pada pembelian ulang, dengan tingkat kepuasan yang tinggi dapat meningkatkan kemungkinan suatu merk dapat melekat dalam ingatan pelanggan.

Pembelian ulang (repeat purchase) adalah kegiatan pembelian yang dilakukan lebih dari satu kali atau beberapa kali. Kepuasan yang diperoleh seorang konsumen, dapat mendorong ia melakukan pembelian ulang (repeat purchase), yang akhirnya menjadi loyal terhadap produk atau loyal terhadap toko tempat dia membeli barang sehingga konsumen dapat menceritakan hal-hal yang baik kepada orang lain. Menurut Schiffman dan Kanuk (2008:42) perilaku pembelian ulang itu sangat berhubungan dengan konsep dari brand loyalty, dimana kebanyakan perusahaan mendukung karena hal ini memiliki kontribusi yang 
besar untuk kestabilan yang baik didalam market place. Menurut Kapferer dan Laurent (dalam Tjiptono, 2008:231), perilaku pembelian ulang (repeat purchasing behaviour) bisa dijabarkan menjadi dua kemungkinan, yakni loyalitas dan inersia. Faktor pembedanya adalah sensitivitas merek (brand sensitivity) yang didefinisikan sebagai sejauh mana nama merek memainkan peranan kunci dalam pemilihan alternatif dalam kategori produk tertentu. Sensitivitas merek dipengaruhi persepsi terhadap perbedaan antar merek dan tingkat keterlibatan konsumen dalam kategori produk. Perilaku pembelian ulang dalam situasi sensitivitas merek yang kuat dikategorikan sebagai loyalitas, dimana konsumen cenderung membeli ulang merek yang sama dan menganggap pilihan merek sangat penting baginya.

\section{Kerangka Konseptual}

Berdasarkan teori-teori yang dikemukakan, secara sederhana kerangka konseptual dapat digambarkan sebagai berikut :

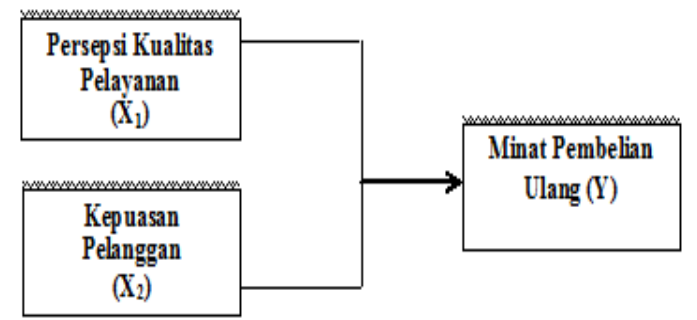

Gambar 1 Kerangka Konseptual

\section{Hipotesis}

Hipotesis adalah dugaan yang sifatnya sementara terhadap rumusan masalah penelitian. Oleh karena itu rumusan masalah penelitian biasanya disusun dalam bentuk kalimat pertanyaan.

Berdasarkan latar belakang masalah, perumusan masalah, dan kerangka konseptual yang telah di uraikan maka hipotesis penelitian ini adalah :

1. Persepsi kualitas pelayanan berpengaruh positif dan signifikan terhadap minat pembelian ulang pada Brastagi Supermarket Rantauprapat.

2. Kepuasan pelanggan berpengaruh positif dan signifikan terhadap minat pembelian ulang pada Brastagi Supermarket Rantauprapat.

3. Persepsi kualitas pelayanan dan kepuasan pelanggan berpengaruh positif dan signifikan terhadap minat pembelian ulang pada Brastagi Supermarket Rantauprapat.

\section{Metode Penelitian \\ Populasi dan Sampel}

Populasi dalam penelitian ini adalah konsumen yang berbelanja di Brastagi Supermarket Rantauprapat, dimana jumlahnya tidak dapat diketahui secara pasti.

Karena populasi dalam penelitian ini tidak diketahui secara pasti jumlahnya, maka untuk menentukan sampel digunakan rumus Supramono dan Haryanto (2006:223) sebagai berikut :

Dimana

$$
\boldsymbol{n}=\frac{(Z \alpha)^{2}(P)(Q)}{\delta^{2}}
$$

$\mathrm{N}$ : Jumlah sampel

$\mathrm{Z} \alpha$ : Nilai tabel $\mathrm{Z} \alpha$ berdasarkan tingkat signifikansi tertentu

Bila $\alpha=0,05 \mathrm{Z}=1,67$, Bila $\alpha=0,01 \mathrm{Z}=$ 1,96

$\mathrm{P} \quad$ : Estimasi proporsi populasi yang sesuai dengan kriteria sample

Q : Proporsi populasi yang tidak sesuai sample (1-p)

$\delta \quad$ : Penyimpangan yang ditolerir $(10 \%)$ Penulis memperoleh $\mathrm{n}$ (jumlah sampel) yang besar dan nilai $p$ yang belum diketahui maka dapat digunakan $p$ 
$=0,5$. Dengan demikian, jumlah sampel yang mewakili populasi dalam penelitian ini adalah :

$$
n=\frac{(1,96)^{2}(0,5)(0,5)}{(0,1)^{2}}=96,04
$$

Jadi, jumlah sampel 96,04 orang dan dibulatkan menjadi 96 orang.

Teknik pengambilan sampel menggunakan metode purposive sampling, yaitu teknik pengambilan sampel dengan kriteria tertentu.

\section{Teknik Pengumpulan Data}

Dalam penelitian ini metode yang digunakan dalam pengumpulan data adalah :

1) Kuesioner, adalah teknik pengumpulan data dengan cara memberikan sejumlah pertanyaan yang telah tersusun secara sistematis yang diberikan kepada responden dalam hal ini adalah karyawan Brastagi Supermarket Rantauprapat.

2) Wawancara, adalah suatu cara pengumpulan data yang digunakan oleh peneliti untuk mendapatkan informasi dengan melakukan tanya jawab secara lisan dan tatap muka dengan responden.

3) Studi dokumentasi, yaitu mengadakan pencatatan langsung terhadap dokumen atau arsip yang berhubungan dengan masalah yang diteliti.

\section{Metode Analisis Data Analisis Deskriptif}

Teknik analisis deskriptif merupakan teknik analisis data dimana peneliti mengelompokkan atau memisahkan komponen atau bagian yang relevan dari keseluruhan data serta merupakan salah satu bentuk analisis untuk menjadikan data mudah dikelola (Kuncoro, 2009:192).

\section{Uji Asumsi Klasik}

Uji Normalitas data

Tujuan uji normalisasi adalah untuk mengetahui apakah distribusi sebuah data mengikuti atau mendekati distribusi normal. Uji normalitas dilakukan dengan pendekatan grafik dengan menggunakan tingkat signifikansi 5\%. Jika nilai Asyimp.Sig (2-tailed) lebih besar dari $5 \%$ artinya data variabel berdistribusi normal (Situmorang dkk, 2010:100).

\section{Uji Heterokedastisitas}

Uji heterokedastisitas berarti varians variabel independen adalah konstan atau sama untuk setiap nilai tertentu variabel independen (homokedastisitas). Model regresi yang baik adalah tidak terjadi heterokedastisitas diuji dengan menggunakan uji Glejser dengan pengambilan keputusan jika variabel independen signifikan secara statistik mempengaruhi variabel dependen, maka ada indikasi terjadi heterokedastisitas. Jika probabilitas signifikannya diatas tingkat kepercayaan 5\% dapat disimpulkan model regresi tidak mengarah adanya heterokedastisitas (Situmorang dkk, 2012:107).

\section{Uji Multikolinearitas}

Uji multikolinearitas variabel independen yang satu dengan yang lain dalam model regresi berganda tidak saling berhubungan secara sempurna atau mendekati sempurna. Untuk mengetahui ada tidaknya gejala multikolinearitas dapat dilihat dari besarnya nilai Tolerance dan VIF (Variance Inflation Factor) melalui program SPSS.

Tolerance mengukur variabelitas variabel terpilih yang tidak dijelaskan oleh variabel independen lainnya. Nilai umumnya yang biasa dipakai adalah nilai 
Tolerance $>0,1$ atau nilai $\mathrm{VIF}<5$, maka tidak terjadi multikolinearitas (Situmorang dkk, 2012:133).

\section{Analisis Regresi Linier Berganda}

Digunakan untuk mengetahui besarnya pengaruh variabel independent yaitu persepsi kualitas pelayanan $\left(\mathrm{X}_{1}\right)$ dan kepuasan pelanggan $\left(\mathrm{X}_{2}\right)$ terhadap variabel dependent yaitu minat pembelian ulang (Y). Untuk memperoleh hasil yang lebih terarah, maka peneliti menggunakan bantuan program software SPSS 20.0 for windows. Rumusnya :

$$
\begin{array}{ll}
\text { Keterangan : } \\
\mathrm{Y} \quad=\text { Minat pembelian ulang } \\
\mathrm{a} & =\text { Konstanta } \\
\mathrm{b}_{1}, \mathrm{~b}_{2} & =\text { Koefisien regresi } \\
\mathrm{X}_{1} & =\text { Persepsi kualitas pelayanan } \\
\mathrm{X}_{2} & =\text { Kepuasan pelanggan } \\
e & =\text { Standar error }
\end{array}
$$$$
\mathbf{Y}=\mathbf{a}+\mathbf{b}_{1} \mathbf{X}_{1}+\mathbf{b}_{2} \mathbf{X}_{2}+e
$$

\section{Uji Hipotesis}

\section{Uji Signifikansi Parsial (Uji t)}

Uji $t$ yaitu menguji apakah variabel bebas secara parsial mempunyai pengaruh signifikan terhadap nilai variabel terikat. Rumusan hipotesis untuk pengujian thitung adalah sebagai berikut :

- $\mathrm{H}_{0}: \mathrm{b}_{1}=\mathrm{b}_{2}=0$, artinya secara parsial tidak terdapat pengaruh yang positif dan signifikan dari variabel bebas yaitu persepsi kualitas pelayanan $\left(\mathrm{X}_{1}\right)$ dan kepuasan pelanggan $\left(\mathrm{X}_{2}\right)$ terhadap variabel terikat yaitu minat pembelian ulang (Y).

- $\mathrm{H}_{\mathrm{a}}: \mathrm{b}_{1} \neq \mathrm{b}_{2} \neq 0$, artinya secara parsial terdapat pengaruh yang positif dan signifikan dari variabel bebas yaitu persepsi kualitas pelayanan $\left(\mathrm{X}_{1}\right)$ dan kepuasan pelanggan $\left(\mathrm{X}_{2}\right)$ terhadap variabel terikat yaitu minat pembelian ulang (Y). yaitu :
- Jika $t_{\text {hitung }} \leq \mathrm{t}_{\text {tabel }}$ pada $\alpha=5 \%$, maka $\mathrm{H}_{0}$ diterima dan $\mathrm{H}_{\mathrm{a}}$ ditolak.

- Jika $_{\text {hitung }} \geq \mathrm{t}_{\text {tabel }}$ pada $\alpha=5 \%$, maka $\mathrm{H}_{0}$ ditolak dan $\mathrm{H}_{\mathrm{a}}$ diterima.

b. Uji Signifikansi Simultan (Uji F)

Uji $F$ bertujuan untuk menunjukkan apakah semua variabel bebas yang dimasukkan ke dalam model secara simultan atau bersama-sama mempunyai pengaruh terhadap variabel terikat. Rumusan hipotesis untuk kasus pengujian F-test di atas, yaitu :

- $\mathrm{H}_{0}: \mathrm{b}_{1}=\mathrm{b}_{2}=0$, artinya tidak ada pengaruh yang signifikan dari variabel bebas yaitu persepsi kualitas pelayanan $\left(\mathrm{X}_{1}\right)$ dan kepuasan pelanggan $\left(\mathrm{X}_{2}\right)$ secara simultan terhadap variabel terikat yaitu minat pembelian ulang (Y).

- $\mathrm{H}_{\mathrm{a}}: \mathrm{b}_{1} \neq \mathrm{b}_{2} \neq 0$, artinya ada pengaruh yang signifikan dari variabel bebas yaitu persepsi kualitas pelayanan $\left(\mathrm{X}_{1}\right)$ dan kepuasan pelanggan $\left(\mathrm{X}_{2}\right)$ secara simultan terhadap variabel terikat yaitu minat pembelian ulang (Y).

Kriteria pengambilan keputusan, yaitu :

- Jika $F_{\text {hitung }} \leq \mathrm{F}_{\text {tabel }}$ pada $\alpha=5 \%$, maka $\mathrm{H}_{0}$ diterima dan $\mathrm{H}_{\mathrm{a}}$ ditolak.

- Jika $F_{\text {hitung }} \geq \mathrm{F}_{\text {tabel }}$ pada $\alpha=5 \%$, maka $\mathrm{H}_{0}$ ditolak dan $\mathrm{H}_{\mathrm{a}}$ diterima.

\section{Koefisien Determinasi $\left(\boldsymbol{R}^{2}\right)$}

Koefisien determinasi digunakan untuk mengukur seberapa besar kemampuan model dalam menerangkan variabel terikat. Koefisien determinan menunjukkan besarnya kemampuan variabel bebas yaitu persepsi kualitas pelayanan $\left(\mathrm{X}_{1}\right)$ dan kepuasan pelanggan $\left(\mathrm{X}_{2}\right)$ dalam menjelaskan variabel terikat yaitu minat pembelian ulang (Y). Mempunyai nilai antara $0-1$ dimana nilai yang mendekati 1 berarti semakin tinggi kemampuan variabel terikat dalam menjelaskan variabel bebasnya. Jika 
determinan $\left(R^{2}\right)$ semakin besar (mendekati satu) maka dapat dikatakan bahwa pengaruh variabel bebas yaitu persepsi kualitas pelayanan $\left(\mathrm{X}_{1}\right)$ dan kepuasan pelanggan $\left(\mathrm{X}_{2}\right)$ terhadap variabel terikat yaitu minat pembelian ulang (Y) adalah kuat. Sebaliknya, jika determinan $\left(R^{2}\right)$ semakin kecil (mendekati nol), maka dapat dikatakan bahwa variabel bebas yaitu persepsi kualitas pelayanan $\left(\mathrm{X}_{1}\right)$ dan kepuasan pelanggan $\left(X_{2}\right)$ terhadap variabel terikat yaitu pembelian ulang (Y) adalah lemah.

\section{Hasil Dan Pembahasan \\ Hasil Penelitian \\ Uji Asumsi Klasik \\ Uji Normalitas}

Uji normalitas bertujuan untuk menguji apakah dalam model regresi, variabel pengganggu atau residual memiliki distribusi normal. Ada dua cara untuk mendeteksi apakah residual berdistribusi normal atau tidak yaitu dengan analisis grafik dan uji statistik. Jika data menyebar disekitar garis diagonal dan mengikuti arah garis diagonal, maka model regresi memenuhi asumsi klasik.

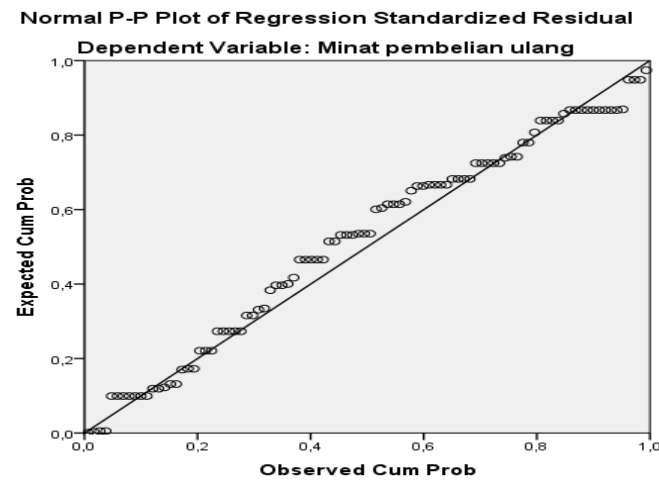

Gambar 2 Grafik P-Plot Uji Normalitas
Pada gambar dapat dilihat bahwa data (titik-titik) menyebar di sekitar garis diagonal dan mengikuti garis diagonal. Oleh karena itu, berdasarkan gambar (Normal P-P Plot Of Regression Standardized Residual) dan gambar maka dapat diambil kesimpulan bahwa data telah memenuhi uji normalitas.

Untuk memastikan apakah data disepanjang garis diagonal berdistribusi normal maka dilakukan uji Kolmogorv Smirnov (1 Sample KS) dengan melihat data residual apakah berdistribusi normal (Situmorang dkk, 2010:100).

\section{Tabel 1}

Hasil Uji Kolmogorov-Smirnov

One-Sample Kolmogorov-Smimov Test

\begin{tabular}{|ll|r|}
\hline & & \multicolumn{1}{|c|}{$\begin{array}{c}\text { Unstandardized } \\
\text { Residual }\end{array}$} \\
\hline $\mathrm{N}$ & Mean & $0 \mathrm{E}-7$ \\
Normal Parameters & St. Deviation &, 91901071 \\
& Absolute &, 091 \\
Most Extreme Diferences & Positive &, 087 \\
& Negative & -091 \\
Kolmogorov-Smirnov Z & &, 895 \\
Asymp. Sig. (2-tailed) &, 400 \\
\hline a. Test distribution is Normal. & \\
b. Calculated from data.
\end{tabular}

Sumber : Hasil Pengolahan Data SPSS (2016)

Pada tabel terlihat bahwa nilai Asymp.Sig. (2-tailed) adalah 0,400. Dengan kata lain variabel residual berdistribusi normal.

\section{Uji Heteroskedostisitas}

Ada dua pendekatan untuk mendeteksi ada atau tidaknya heteroskedastisitas, yaitu :

1) Pendekatan Grafik (Grafik Scatterplot) Dasar analisis adalah jika tidak ada pola yang jelas, serta titik-titik menyebar baik di atas dan di bawah angka 0 pada sumbu Y, maka tidak terjadi heteroskedastisitas. 


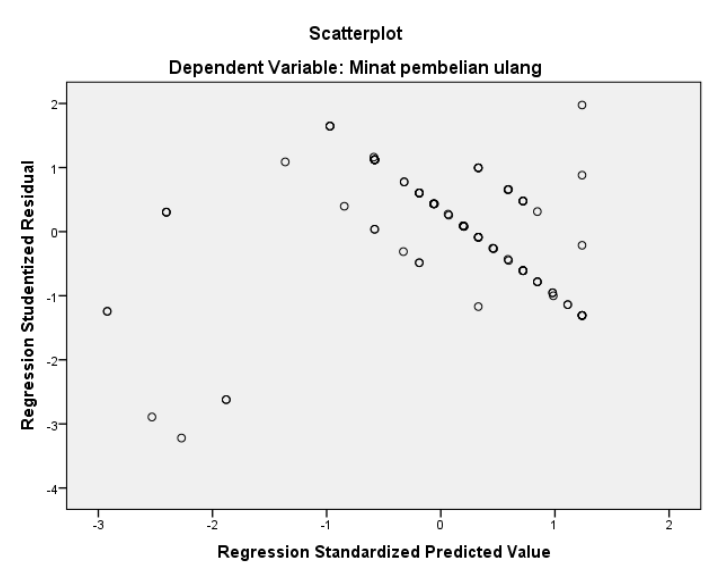

Gambar 3 Scatterplot

Berdasarkan Gambar diatas dapat terlihat bahwa tidak ada pola yang jelas, serta titik-titik menyebar baik di atas dan di bawah angka 0 pada sumbu Y, maka berdasarkan metode grafik tidak terjadi heteroskedastistas pada model regresi.

2) Uji Glejser

Uji Glejser mengusulkan untuk meregres nilai absolut residual terhadap variabel independen. Jika variabel independen signifikan secara statistik mempengaruhi variabel independen, maka ada indikasi terjadi heteroskedastisitas.

Tabel 2

Hasil Uji Glejser

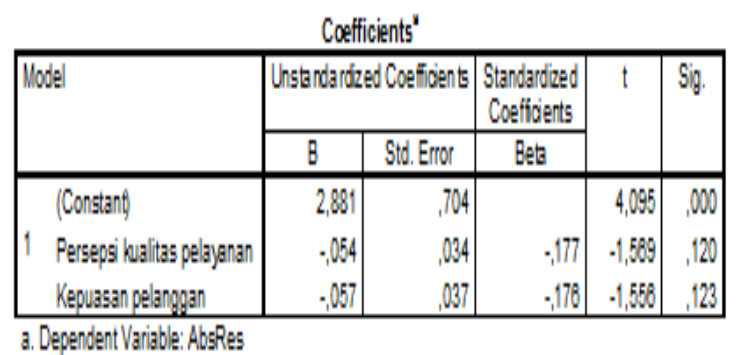

Sumber : Hasil Pengolahan Data SPSS (2016)

Berdasarkan Tabel diatas dapat diketahui bahwa tidak satupun variabel independen yang signifikan secara statistik mempengaruhi variabel dependen Absolut Residual (AbsRes). Hal ini terlihat dari probabilitas signifikansinya di atas tingkat kepercayaan 0,05, dengan demikian hasil uji Glejser sesuai dengan metode grafik bahwa pada model regresi tidak terjadi heteroskedastisitas.

\section{Uji Multikolinearitas}

Uji Multikolinearitas bertujuan untuk menguji adanya korelasi antara variabel independen. Jika terjadi korelasi maka dinamakan multikol, yaitu adanya masalah multikolinearitas. Model regresi yang baik seharusnya tidak terjadi korelasi antara variabel independen. Hasil pengolahan dapat dilihat pada tabel sebagai berikut :

Tabel 3

\section{Hasil Uji Multikolinearitas}

Coefficients"

\begin{tabular}{|c|c|c|c|c|c|c|c|}
\hline \multirow[t]{2}{*}{ |lodele } & \multicolumn{2}{|c|}{$\begin{array}{l}\text { Ungerndardided } \\
\text { Cosificents }\end{array}$} & \multirow{2}{*}{\begin{tabular}{|c|}
$\begin{array}{l}\text { Sardadiced } \\
\text { Coeficicants }\end{array}$ \\
Befla \\
\end{tabular}} & \multirow[t]{2}{*}{$\mathrm{t}$} & \multirow[t]{2}{*}{ Sig. } & \multicolumn{2}{|c|}{ 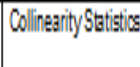 } \\
\hline & $B$ & St. Error & & & & Toleance & VIF \\
\hline (Constant) & 4,14 & 1,212 & & 3,418 & .001 & & \\
\hline Perexosi Kualibs pelaganan & 31 & .069 & .383 & 5,378 & .000 &, 784 & 1,309 \\
\hline Kepussan pelangazan & 48. & .083 & .541 & 7,002 & .000 & 7864 & $1,30:$ \\
\hline
\end{tabular}

Sumber : Hasil Pengolahan Data SPSS (2016)

Hasil pengujian ini adalah pedoman suatu model regresi yang bebas multikolinearitas adalah dengan melihat variance inflation factor (VIF) dan tolerance. Jika VIF $<5$, dan nilai tolerance harus mendekati > 0,1 maka tidak terdapat masalah multikolinearitas. Pada tabel dapat dilihat bahwa nilai VIF $<5$ dan nilai tolerance $>0,1$ dengan demikian tidak ditemukan masalah multikol pada model regresi hasil penelitian.

\section{Analisis Regresi Linear Berganda}

Dalam melakukan analisis regresi linear berganda digunakan bantuan aplikasi SPSS 20.0 for windows. Hasil 
pengolahan data ditampilkan seperti pada Tabel berikut :

\section{Tabel 4}

Analisis Regresi Linear Berganda

\begin{tabular}{|c|c|c|c|c|c|}
\hline & \multicolumn{2}{|c|}{ Coefficients" } & & & \\
\hline \multirow[t]{2}{*}{ Model } & \multicolumn{2}{|c|}{$\begin{array}{c}\text { Unstandardized } \\
\text { Coefficents }\end{array}$} & $\begin{array}{l}\text { Sendardized } \\
\text { Coeficients }\end{array}$ & \multirow[t]{2}{*}{$t$} & \multirow[t]{2}{*}{ Sig. } \\
\hline & $B$ & Stt. Error & Beta & & \\
\hline$($ Constant) & 4,141 & 1,212 & & 3,418 &, 001 \\
\hline 1 Persepsikualitas pelajanan & 317 & ,069 & .383 & 5,378 & .000 \\
\hline Kepuasan pelanggan & .480 &, 083 & .541 & 7,802 &, 000 \\
\hline
\end{tabular}

Sumber : Hasil Pengolahan Data SPSS (2016)

Berdasarkan Tabel diatas pada kolom B Unstandardized Coefficients maka dapat dibentuk persamaan sebagai berikut :

$$
\begin{aligned}
& \mathbf{Y}=\mathbf{4 , 1 4 1}+\mathbf{0 , 3 1 7} \mathbf{X}_{\mathbf{1}}+\mathbf{0 , 4 8 0} \mathbf{X}_{\mathbf{2}}+\boldsymbol{e} \\
& \mathrm{a}= 4,141, \text { artinya bahwa jika } \\
& \text { persepsi kualitas pelayanan dan } \\
& \text { kepuasan pelanggan dianggap } \\
& \text { tidak ada, maka minat } \\
& \text { pembelian ulang sebesar } 4,141 . \\
& \mathrm{b}_{1}= 0,317 \text {, artinya bahwa jika } \\
& \text { variabel persepsi kualitas } \\
& \text { pelayanan }\left(\mathrm{X}_{1}\right) \text { naik satu satuan } \\
& \text { dan variabel lainnya tetap, akan } \\
& \text { menambah minat pembelian } \\
& \text { ulang sebesar } 0,317 . \\
& \mathrm{b}_{2}= 0,480, \text { artinya bahwa jika } \\
& \text { variabel kepuasan konsumen } \\
&\left(\mathrm{X}_{2}\right) \text { naik satu satuan dan } \\
& \text { variabel lainnya tetap, akan } \\
& \text { menambah minat pembelian } \\
& \text { ulang sebesar } 0,480 .
\end{aligned}
$$

Dari persamaan tersebut, diketahui bahwa semua koefisien regresi bernilai positif. Dengan demikian persepsi kualitas pelayanan dan kepuasan konsumen berpengaruh secara positif terhadap minat pembelian ulang.

\section{Pengujian Hipotesis}

\section{Uji Signifikansi Parsial (Uji t)}

Uji $t$ ini menunjukkan seberapa besar pengaruh variabel bebas $(\mathrm{X})$ secara parsial/individu terhadap variabel terikat (Y). Uji t dilakukan dengan cara membandingkan nilai $t_{\text {hitung }}$ dengan $t_{\text {tabel }}$ dengan kriteria pengambilan keputusan adalah :

- $\mathrm{H}_{0}$ diterima jika $\mathrm{t}_{\text {hitung }}<\mathrm{t}_{\text {tabel }}$ pada $\alpha=$ $5 \%$.

- Ha diterima jika $\mathrm{t}_{\text {hitung }}>\mathrm{t}_{\text {tabel }}$ pada $\alpha=$ $5 \%$.

Nilai $t_{\text {hitung diperooleh dari hasil }}$ pengolahan data dengan SPSS, sedangkan $t_{\text {tabel }}$ yang digunakan adalah nilai distribusi t untuk 96 responden ( $\mathrm{df}=\mathrm{n}-\mathrm{k}$ $=96-3=93$ ) dan $\alpha=5 \%$ yaitu sebesar 1,66140 .

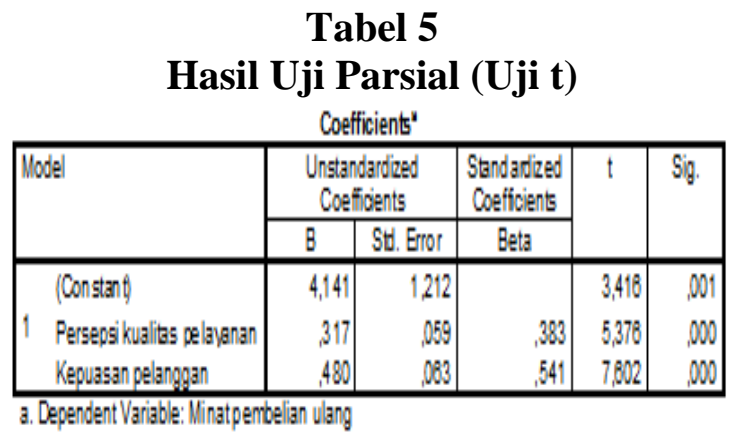

Sumber : Hasil Pengolahan Data SPSS, 2016

Berdasarkan Tabel diatas, maka dapat dijelaskan sebagai berikut :

1) Untuk variabel persepsi kualitas pelayanan $\left(\mathrm{X}_{1}\right)$, diperoleh nilai $\mathrm{t}_{\text {hitung }}>$ $\mathrm{t}_{\text {tabel }}$ yaitu $5,376>1,66140$ dengan signifikansi $0,000<0,05$. Hasil tersebut menunjukkan bahwa persepsi kualitas pelayanan berpengaruh signifikan terhadap minat pembelian ulang pada Brastagi Supermarket Rantauprapat. Dengan demikian hipotesis dapat diterima.

2) Untuk variabel kepuasan konsumen $\left(\mathrm{X}_{2}\right)$, diperoleh nilai $\mathrm{t}_{\text {hitung }}>\mathrm{t}_{\text {tabel }}$ yaitu 
7,602 > 1,66140 dengan signifikansi $0,000<0,05$. Hasil tersebut menunjukkan bahwa kepuasan konsumen berpengaruh signifikan terhadap minat pembelian ulang pada Brastagi Supermarket Rantauprapat. Dengan demikian hipotesis dapat diterima.

\section{Uji Signifikansi Simultan (Uji F)}

Uji $F$ digunakan untuk menguji pengaruh persepsi kualitas pelayanan $\left(\mathrm{X}_{1}\right)$ dan kepuasan konsumen $\left(\mathrm{X}_{2}\right)$ secara bersama-sama terhadap minat pembelian ulang pada Brastagi Supermarket Rantauprapat (Y). Uji F dilakukan dengan membandingkan $\mathrm{F}_{\text {hitung }}$ dan $\mathrm{F}_{\text {tabel }}$.

Kriteria pengambilan keputusan adalah :

- $\mathrm{H}_{0}$ diterima jika $\mathrm{F}_{\text {hitung }}<\mathrm{F}_{\text {tabel }}$ pada $\alpha$ $=5 \%$.

- Ha diterima jika $F_{\text {hitung }}>F_{\text {tabel }}$ pada $\alpha$ $=5 \%$.

Nilai $F_{\text {hitung diperoleh dengan }}$ menggunakan software SPSS 20.0 for Windows, kemudian akan dibandingkan dengan nilai $F_{\text {tabel }}$ pada tingkat $\alpha=5 \%$ dengan derajat bebas yaitu df1 $=3-1=2$, dan df $2=96-3=93$. Maka $F_{\text {tabel }}$ yang digunakan adalah nilai $\mathrm{F}_{0,05}(2: 93)=3,09$.

\section{Tabel 6}

Hasil Uji Simultan (Uji F)

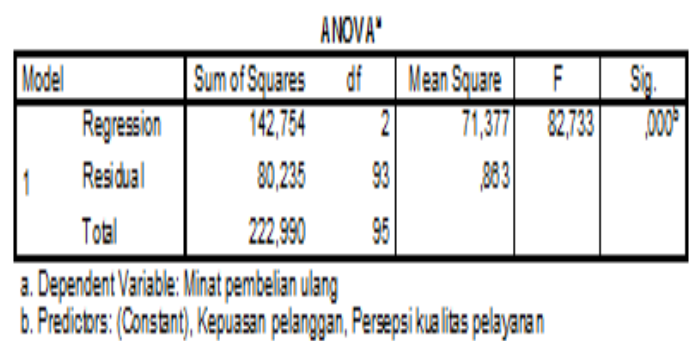

Sumber : Hasil Pengolahan Data SPSS, 2016

Berdasarkan Tabel diatas bahwa nilai $F_{\text {hitung }}>F_{\text {tabel }}(82,733>3,09)$ dengan taraf signifikansi $0,000<0,05$ menunjukkan bahwa persepsi kualitas pelayanan dan kepuasan konsumen secara bersama-sama berpengaruh positif dan signifikan terhadap minat pembelian ulang pada Brastagi Supermarket Rantauprapat. Dengan demikian hipotesis dapat diterima.

Koefisien Determinasi $\left(\boldsymbol{R}^{2}\right)$

Pengujian koefisien determinasi $\left(R_{2}\right)$ bertujuan untuk mengetahui seberapa besar kemampuan variabel bebas menjelaskan variabel terikat. Dalam output SPSS, koefisien determinasi terletak pada tabel Model Summary dan tertulis $R$ Square. Namun untuk regresi linear berganda sebaiknya menggunakan nilai $R$ Square yang sudah disesuaikan atau tertulis Adjusted $R$ Square, karena disesuaikan dengan jumlah variabel bebas dalam penelitian. Nilai $R$ Square dikatakan baik jika di atas 0,5 karena nilai $R$ Square berkisar antara 0 sampai 1 .

Tabel 7

\section{Koefisien Determinasi}

Model Summary

\begin{tabular}{|c|c|c|c|c|}
\hline Model & $R$ & R Square & $\begin{array}{c}\text { Adjusted R } \\
\text { Square } \\
\end{array}$ & $\begin{array}{c}\text { Std. Error of the } \\
\text { Estimate }\end{array}$ \\
\hline 1 & $.800^{\circ}$ & 840 &, 032 &, 929 \\
\hline
\end{tabular}

Sumber : Hasil Pengolahan Data SPSS, 2016

Berdasarkan Tabel diatas dapat dijelaskan sebagai berikut :

1) Nilai $R=0,800$ berarti hubungan antara persepsi kualitas pelayanan $\left(\mathrm{X}_{1}\right.$ dan kepuasan pelanggan $\left(\mathrm{X}_{2}\right)$ terhadap minat pembelian ulang pada Brastagi Supermarket Rantauprapat (Y) sebesar $80,0 \%$. Artinya hubungan antar variabel sangat kuat.

2) Nilai Adjusted $R$ square sebesar 0,632 berarti $63,2 \%$ minat pembelian ulang dapat dijelaskan oleh variabel persepsi kualitas pelayanan $\left(\mathrm{X}_{1}\right)$ dan kepuasan 
pelanggan $\left(\mathrm{X}_{2}\right)$, sedangkan sisanya $36,8 \%$ dapat dijelaskan oleh faktor lain yang tidak diteliti oleh penelitian ini.

3) Standard Error of Estimated (standar deviasi) bernilai 0,929 yang berarti model regresi dinilai baik, karena semakin kecil standar deviasi berarti model akan semakin baik.

\section{Pembahasan}

Melalui uji signifikansi parsial (Uji t) diketahui bahwa variabel persepsi kualitas pelayanan berpengaruh positif dan signifikan terhadap minat pembelian ulang. Hasil ini menunjukkan bahwa penilaian yang baik terhadap kualitas pelayanan sesuai dengan tingkat keinginan konsumen dalam melakukan pembelian ulang. Pada umumnya konsumen dalam membelanjakan uangnya akan memperhitungkan kualitas pelayanan yang diperoleh dari pembelian produk. Dengan demikian, konsumen akan mempertimbangkan kualitas pelayanan sebagai penukaran dari pengorbanan uang yang digunakan konsumen dalam membeli produk.

Dalam penelitian Tandanu (2009) menunjukkan bahwa kualitas pelayanan mempunyai nilai hitung yang lebih tinggi ketimbang dengan lokasi usaha, ini berarti pentingnya kualitas pelayanan sebagai penujang keberhasilan dalam melakukan pembelian ulang.

Apabila ada konsumen yang merasa tidak puas akan persepsi kualitas pelayanan yang diberikan oleh Brastagi Supermarket, ketidakpuasan tersebut akan cepat tersebar dari mulut ke mulut, maka akan merubah citranya di hadapan konsumen. Oleh sebab itu, Brastagi Supermarket harus memberikan kualitas pelayanan yang memuaskan konsumen sehingga konsumen merasa bangga menggunakan produk dan mereka juga akan terus menggunakan produk dalam waktu jangka panjang.

Variabel kepuasan pelanggan $\left(\mathrm{X}_{2}\right)$ berpengaruh positif dan signifikan terhadap minat pembelian ulang pada Brastagi Supermarket Rantauprapat, yang dapat ditunjukkan pada pengujian hipotesis kedua. Dalam penelitian ini responden menilai bahwa kepuasan pelanggan terhadap suatu produk mempunyai nilai tambah terhadap pembelian. Hal itu menyebabkan terjadinya pembelian ulang produk. Pada kepuasan pelanggan $\left(\mathrm{X}_{2}\right)$ inilah yang menjadikan faktor dominan dalam mempengaruhi pembelian ulang produk pada Brastagi Supermarket Rantauprapat.

Dalam penelitian, Andre (2009) menyatakan bahwa konsumen yang loyal tidak selalu puas, tetapi konsumen yang puas cenderung loyal. Dengan demikian Brastagi Supermarket Rantauprapat harus membangun kepuasan pelanggan karena konsumen yang puas akan cenderung loyal. Penelitian Ayu (2009) tingkat kepuasan kemungkinan dapat meningkatkan suatu merk melekat dalam ingatan konsumen dan meningkatkan pilihan konsumen terhadap merk tersebut. Hal ini mengidentifikasi bahwa semakin tinggi kepuasan konsumen terhadap suatu merk, semakin tinggi pilihan konsumen terhadap merk tersebut. Begitu sebaliknya, semakin rendah kepuasan yang dirasakan konsumen terhadap suatu merk maka semakin rendah pula pilihan konsumen terhadap produk tersebut. Yang pada akhirnya konsumen pindah menggunakan produk lain.

Berdasarkan hasil penelitian yang dilakukan, pada uji signifikansi simultan (Uji F) menunjukkan bahwa $F_{\text {tabel }}(82,733$ $>3,09)$ dengan nilai Sig 0,000 yang berarti lebih kecil daripada $(0,000<0,05)$ maka kesimpulan yang didapat adalah $\mathrm{Ha}$ 
diterima dan Ho ditolak yang berarti secara bersama-sama persepsi kualitas pelayanan dan kepuasan pelanggan signifikan terhadap pembelian ulang pada Brastagi Supermarket Rantauprat. Hal ini sejalan dengan penelitian sebelumnya yaitu Ayu (2009) yang meyatakan bahwa secara serempak pengaruh perceived quality. Perceived value, brand preference customer satisfaction dan customer loyalty adalah signifikan pada repurchase intention.

Berdasarkan pengujian koefisien determinasi bahwa hubungan antara kualitas pelayanan dan kepuasan pelanggan terhadap pembelian ulang produk sebesar $80,0 \%$ yang bertanda positf, hal ini menunjukkan adanya hubungan yang sangat kuat antara persepsi kualitas pelayanan dan kepuasan pelanggan terhadap minat pembelian ulang produk pada Brastagi Supermarket Rantauprapat. Dengan demikian, apabila Brastagi Supermarket Rantauprapat melakukan perbaikan terus-menerus terhadap kualitas pelayanan yang dberikan, maka secara langsung berpengaruh positif terhadap kepuasan pelanggan yang akhirnya konsumen akan melakukan pembelian ulang secara terusmenerus dalam waktu jangka panjang. Dari hasil determinasi diperoleh nilai Adjusted $R$ Square sebesar 0,632, yang berarti $63,2 \%$ minat pembelian ulang produk dapat dijelaskan oleh persepsi kualitas pelayanan dan kepuasan pelanggan, sedangkan sisanya $36,8 \%$ dapat dijelaskan oleh faktor-faktor lain yang tidak diteliti dalam penelitian ini. Untuk itu, Brastagi Supermarket Rantauprapat harus terus meningkatkan kualitas pelayanan dan kepuasan pelanggan serta mengembangkan faktorfaktor lainnya yang tidak diteliti tersebut.

\section{Kesimpulan Dan Saran Kesimpulan}

Dari hasil analisis dan pembahasan yang telah diuraikan pada bab sebelumnya, maka dapat ditarik kesimpulan dari penelitian ini adalah :

1. Persepsi kualitas pelayanan secara parsial berpengaruh positif dan signifikan terhadap minat pembelian ulang pada Brastagi Supermarket Rantauprapat, dimana nilai $t_{\text {hitung }}>t_{\text {tabel }}$ yaitu $5,376>1,66088$ dengan signifikansi $0,000<0,05$.

2. Kepuasan pelanggan secara parsial berpengaruh positif dan signifikan terhadap minat pembelian ulang pada Brastagi Supermarket Rantauprapat, dimana nilai $t_{\text {hitung }}>t_{\text {tabel }}$ yaitu 7,602 > 1,66088 dengan signifikansi $0,000<$ 0,05 .

3. Persepsi kualitas pelayanan dan kepuasan pelanggan secara serempak berpengaruh positif dan signifikan terhadap minat pembelian ulang pada Brastagi Supermarket Rantauprapat, dimana nilai $F_{\text {hitung }}>F_{\text {tabel }}(82,733>$ 2,70) dengan taraf signifikansi $0,000<$ 0,05 .

4. Nilai Adjusted $R$ square sebesar 0,632 menunjukkan bahwa $63,2 \%$ minat pembelian ulang dapat dijelaskan oleh variabel persepsi kualitas pelayanan dan kepuasan pelanggan, sedangkan sisanya $36,8 \%$ dapat dijelaskan oleh faktor lain yang tidak diteliti oleh penelitian ini.

\section{Saran}

Berdasarkan kesimpulan diatas, maka peneliti memberikan saran sebagai berikut :

1. Brastagi Supermarket Rantauprapat harus tetap memperhatikan dan memperbaiki kualitas pelayanan yang diberikan kepada konsumen baik itu layanan maupun keluhan dari 
konsumen, agar konsumen betah dan puas dalam berbelanja dalam waktu jangka panjang.

2. Bagi peneliti lain yang ingin melanjutkan penelitian ini, agar dapat menambahkan jumlah indikator dari variabel-variabel bebas dan variabel terikat. Sehingga mencerminkan arti yang sebenarnya dari variabel penelitian tersebut.

\section{Daftar Pustaka}

Aaker, A. David. 2008. Manajemen Ekuitas Merek. Alih bahasa oleh Aris Ananda. Jakarta : Mitra Utama.

Andre, Y.B. 2009. “Analisis Hubungan Antara Kepuasan Pelanggan dan Loyalitas Pelanggan Terhadap Keinginan Pembelian Ulang, Studi Kasus di Universitas Bunda Mulia". Business and Management Journal Bunda Mulia, Vol 5 No.1 Maret 2009.

Ayu, Yohana Sylvi Putri. 2009. "Perceived Quality. Perceived Value, Brand Preference Customer Satisfaction and Customer Loyalty Pada Repurchase Intention", Jurnal Bisnis dan Manajemen, Vol. 9 No.1 2009 : 75-90.

Burhanudin. 2007. "Analisis Konsekuensi Kepuasan dan Penyesalan Pada Niat Melakukan Pembelian Ulang dan Niat Melakukan Komplain", Skripsi Ekonomi Manajemen, Universitas Sumatera Utara. Medan.

Ferrinadewi, Erna. 2008. Merek dan Psikologi Konsumen. Yogyakarta : Graha Ilmu.

Kasmir. 2006. Etika Customer Service. Jakarta : PT Raja Grafindo Persada.
Kotler, Philip. 2008. Manajemen Pemasaran. Jilid 1 dan 2. Jakarta : PT. Indeks. 2009. Manajemen Pemasaran. Jilid 2. Edisi ketigabelas. Jakarta : Erlangga.

Kuncoro, Mudrajad. 2009. Metode Riset untuk Bisnis \& Ekonomi (Edisi 3). Jakarta : Erlangga.

Laksana, Fajar. 2008. Manajemen Pemasaran ; Pendekatan Praktis. Yogyakarta : Graha Ilmu.

Lupioyadi, Rambat dan A. Hamdani. 2006. Manajeman Pemasaran Jasa, Edisi Kedua, Jakarta : Salemba Empat.

Martin, William B. 2008. Quality Customer Service. Jakarta : PPM.

Schiffman, Leon G. And Leslie L. Kanuk. 2008. Customer Behaviour (Perilaku Konsumen), Edisi 7, Jakarta : PT. Indeks.

Simamora, Bilson. 2006. Membongkar Kotak Hitam Konsumen. Jakarta : PT Gramedia Pustaka Utama.

Situmorang, Syafrizal Helmi, Iskandar Muda, Doli M.Jafar Dalimunthe, Fadli, Fauzie Syarif. 2010. Analisis Data. Medan : USU Press

Situmorang, Syafrizal Helmi, dan Muslich Lufti. 2012. Analisis Data Untuk Manajemen dan Bisnis. Medan : USU Press.

Sugiyono. 2007. Metode Penelitian Bisnis. Bandung : Alfabeta.

Sumarwan, Ujang. 2011. Perilaku Konsumen. Bogor : Ghalia.

Sunarto. 2006. Customer Service. Jakarta : Amus.

Supramono dan Jony Oktavian Haryanto. 2006. Desain Proposal Penelitian Studi Pemasaran. Yogyakarta : Andi.

Supranto, J dan Limakrisna. 2007. Perilaku Konsumen dan Strategis 
Pemasaran. Edisi pertama, Cetakan pertama. Jakarta: Mitra Wacana Media.

Suryani, Tatik. 2008. Perilaku Konsumen - Implikasi Pada Strategi Pemasaran. Yogyakarta : Andi.

Tandanu, Mansur. 2009. "Pengaruh Lokasi Dan Kualitas Pelayanan Terhadap Minat Pembelian Ulang Pada CV Brastagi Supermarket Jl. Gatot Subroto Medan". Skripsi, FEB USU. Medan.

Tjiptono, Fandy. 2008. Pemasaran Jasa. Malang : Penerbit Bayu Media Publishing.

. 2011. Strategi Pemasaran. Yogyakarta : Andi.

Wibisaputra, Adizty. 2011. "Analisis Faktor-Faktor yang Mempengaruhi Minat Beli Ulang Gas Elpiji 3 kg (di PT. Candi Agung Pratama Semarang)". Skripsi Ekonomi Manajemen, Universitas Diponegoro. Semarang. 